\title{
"Building ethical leadership through training and development approach at a higher education institution in South Africa"
}

\begin{tabular}{|c|c|}
\hline AUTHORS & $\begin{array}{l}\text { Anrusha Bhana iD https://orcid.org/0000-0001-5577-6728 } \\
\text { Sachin Suknunan (D https://orcid.org/0000-0002-7296-8059 }\end{array}$ \\
\hline ARTICLE INFO & $\begin{array}{l}\text { Anrusha Bhana and Sachin Suknunan (2020). Building ethical leadership } \\
\text { through training and development approach at a higher education institution in } \\
\text { South Africa. Problems and Perspectives in Management, 18(1), 405-414. } \\
\text { doi:10.21511/ppm.18(1).2020.35 }\end{array}$ \\
\hline DOI & http://dx.doi.org/10.21511/ppm.18(1).2020.35 \\
\hline RELEASED ON & Monday, 06 April 2020 \\
\hline RECEIVED ON & Monday, 09 December 2019 \\
\hline ACCEPTED ON & Thursday, 19 March 2020 \\
\hline LICENSE & $\begin{array}{l}(c) \overline{E Y} \\
\text { This work is licensed under a Creative Commons Attribution } 4.0 \text { International } \\
\text { License }\end{array}$ \\
\hline JOURNAL & "Problems and Perspectives in Management" \\
\hline ISSN PRINT & $1727-7051$ \\
\hline ISSN ONLINE & $1810-5467$ \\
\hline PUBLISHER & LLC "Consulting Publishing Company "Business Perspectives" \\
\hline FOUNDER & LLC "Consulting Publishing Company "Business Perspectives" \\
\hline
\end{tabular}

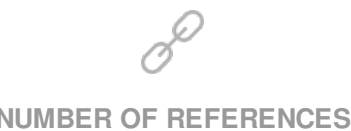

33

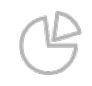

NUMBER OF FIGURES

1

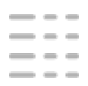

NUMBER OF TABLES

2

(C) The author(s) 2021. This publication is an open access article. 


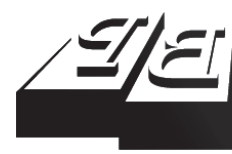

\section{BUSINESS PERSPECTIVES}

(O)

LLC "CPC "Business Perspectives" Hryhorii Skovoroda lane, 10, Sumy, 40022, Ukraine www.businessperspectives.org

Received on: $9^{\text {th }}$ of December, 2019 Accepted on: $19^{\text {th }}$ of March, 2020 Published on: $6^{\text {th }}$ of April, 2020

(c) Anrusha Bhana

Sachin Suknunan, 2020

Anrusha Bhana, Ph.D., Head Department of Financial Accounting, Faculty of Accounting and Informatics, Durban University of Technology, Durban, South Africa.

(Corresponding author)

Sachin Suknunan, Doctor of Business Administration, Student Services Division, University of KwaZulu-Natal, Durban, South Africa.

\section{BUILDING ETHICAL LEADERSHIP THROUGH TRAINING AND DEVELOPMENT APPROACH AT A HIGHER EDUCATION INSTITUTION IN SOUTH AFRICA}

\begin{abstract}
The research has shown that many leaders lack ethical practice, but training and development geared towards ethical leadership can serve to bridge this gap in theory and practice. This paper focuses primarily on the key aspect of training and development to promote more ethical leadership within a higher education institution setting. The data were drawn from a mixed-method study adopting both quantitative and qualitative approaches. Simple random sampling constituted a sample of 312 academic and administrative staff members at the institution. The purposeful sampling for the qualitative component was a realized sample of 3 executive management leadership and 9 line management leadership participants, indicating a total response rate of $67 \%$. The results for executive management leadership reflect poor leadership style from the employees' perspective in relation to respect and fairness, transparency, behavior, and other ethical leadership-related items (of $\mathrm{M}=2.74, \mathrm{SD}=0.033$ ). In addition, there was a clear need for leadership to attend ongoing training courses $(M=4.20, S D=0.904)$. From the qualitative perspective, more than $50 \%$ of the leadership respondents indicated no appropriate university leadership programmes or ethical leadership programs. Therefore, the investment in training and development can promote more ethical leadership style, which in turn can have a positive impact on employees $(\mathrm{M}=4.43, \mathrm{SD}=$ 0.740). In light of this, the results provide a strong inclination towards more training and development programs to ensure that leaders develop ethical considerations in their role as leaders.
\end{abstract}

Keywords ethics, development, employees, leadership, impact, engagement, skills

JEL Classification I23, M14, M53

\section{INTRODUCTION}

This paper examines the importance of ethical leadership from the training and development perspective. Training and development is often underestimated and under-represented when it comes to ethical leadership, yet an imperative part of any public or private organizations' ethical code of conduct (King 3 report or King 4 report) in South Africa. It is often assumed that those occupying leadership positions are already aware of ethics through their vocational experiences. However, this is not often the case, and, as a result, such leaders may promote unethical leadership intentionally or even unintentionally. Continuous learning through consistent training and development hence becomes a mandatory construct in continuously enforcing and promoting ethical leadership.

As human beings, our personal development starts from birth and continues to adulthood. Moreover, personal and professional development happens continuously throughout one's life, as it supports our 
lifelong transformational stage. Thus, any type of professional development should be a continuous process, especially as South Africa enters the 4th Industrial Revolution. Naino (2016, p. 17) suggested that in the current epoch of such fast change and development, the leaders must continually work to advance their capabilities to ensure constant change and frequent adaptation while safeguarding the leader's individuality and morals. Hence, South African higher education institutions (hereafter referred to as SAHEIs) need to ensure that leadership development is a priority at all levels. To lead universities into the post-modern era, Africa needs leaders with a strong interpersonal skill, politically astute, economically perceptive, corporate knowledge, and emotional intelligence (Hanson \& Leautier, 2011, p. 410).

There is a need for higher education (hereafter referred to as HE) leaders to develop new skills and leadership practices to respond effectively to transformation challenges (Herbst \& Conradie, 2011, p. 12). However, leadership development in HE is still an under-investigated research and application discipline (Greasley, 2007, pp. 693-710). Thus, it is important to rethink the education model linked to leadership development, the goals given to managers involving culture, ethics, and the message conveyed (Naidu-Hoffmeester, 2014). Although, there are many examples of strong, upright, and moral leadership universally, the skills to support executive and lower-level leadership to become better leaders have been ignored. Seemingly, some South African Higher Education Institutions have been led by people with leadership incompetence. Today, the global economy requests for the development of management skills, innovative approaches, and competitive advantages of Higher Education Institutions (Taylor \& Machado, 2006, p. 154). The White Paper proposed sound governance, robust management, astute and effective leadership as important prerequisites for the transformation of Higher Education and training area (De La Rey, 2015).

Interesting discussions were made on Higher Education needs to develop leadership skills that would be able to identify and handle the external environment changes and preserve the institutions' goals (Kivipold \& Vadi, 2008). The building of ethical leadership skills remains underdeveloped and split, despite skills development programs and other institutional programs at the HEIs. Inherently, Sankar (2003) claimed that besides universities hiring and developing leaders, there is a need to nurture and support ethical qualities and behaviors considered necessary in those leaders. However, Ngcamu and Teferra (2015b, p. 130) asserted that people ascend to leadership ranks without being trained through leadership development programs. Thus, there is a need for the development of respective employees to leadership positions, which will support the institutions' strategic agenda. This study will be a discourse on ethical leadership training and development and the importance thereof.

\section{LITERATURE REVIEW}

\subsection{South African higher education institutions (SAHEI) and leadership}

In the global south, HEIs have a vital responsibility regarding the development of the nation's states (van Schalkwyk et al., 2014, p. 6). One can acknowledge that South African HEIs are gradually becoming challenging places to rule, manage, and lead (Mabelebele, 2013, p. 2). It is noteworthy to express that the leaders of universities are not equivalent to the leaders of other categories of creative organizations (African Minds, 2016, p. 49). Moreover, the customary function of HEIs is serving society, through setting the foundation for viable employment, training for social responsibility, individual development, and growth of knowledge base (Gumede, 2015, p. 157). Notably, HEIs should be at the forefront of the formation of new knowledge, modernism, development of professionals, and imparting democratic principles (van Schalkwyk et al., 2014, p. 6). Bush (2007, p. 395) claimed that transformational leadership skill proposes a vision that combines purpose and galvanizes different internal stakeholders into action and crucial for HEIs development. Evidently, HE today is confronted with the challenge to build a system that will be operational to meet the needs of people in the next century (van Niekerk, 2005, p. 2). According to Awung (2014, p. 29), in terms of skills, development, and research, Higher Education plays a pivotal role in contributing to 
human resource and information society development in South Africa.

\subsection{Leadership development and training}

\subsubsection{Current trends in HEls leadership development and training}

Hudea (2014, p. 114) asserted that leaders develop over time within the organization, by observation, education, training, networking, or skills, through leading oneself, individuals, and groups of people. A study in eight SAHEIs showed that all institutions identified the resources for the availability of professional development funding as necessary (Leibowitz, Bozalek, van Schalkwyk, \& Winberg, 2015, pp. 315-330). However, knowledge and talent like other tangible assets, if neglected, depreciate in value (Kouzes \& Posner, 2003, p. 334). Inherently, most of the HEIs have given little attention to leadership development, which caused ineffectiveness and lack of leadership capabilities (Ngcamu \& Teferra, 2015a, p. 208). Moreover, Taylor and Machado (2006, p. 156) assert that very often altruistic employees are thrust into leadership roles, devoid of the essential capabilities.

It is noteworthy that many researchers have documented that academics are ill-prepared to deal with HE transformational challenges despite training and development opportunities being offered as proper support, which is often overlooked (Ngcamu \& Teferra, 2015b, p. 132). Moreover, another concern among the academic staff was that often, the well-intended development programs were unrelated to university leadership needs (Ngcamu \& Teferra, $2015 a, b)$. Zuber-Skerritt (2007, p. 985) claims that the need for transformation internationally from learning, teaching, employee development, and leadership in higher education has long been documented. Additionally, researchers claimed that academics believe that contents and elements of staff development programs recommended were low. According to Ngcamu and Teferra (2015b, p. 133), many universities offer little or no proper training for line management leadership and others at different levels of leadership and management. MacGregor (2015, p. 25 ) asserts that a university vice-chancellor vastly invests in the development of other people not only in terms of individual time and energy but also in rela- tion to institutional resources. Ngcamu and Teferra (2015b, p. 130) suggest that leadership development in HE is of crucial importance to the future of South Africa.

\subsubsection{Leadership engagement}

Most reflections hint on the seam of leadership, which is the face-to-face interactional dimension: dealing with employees, students, council members (African Minds, 2016). Moreover, good leaders must be entirely involved in and be knowledgeable about different aspects of the institution (African Minds, 2016). The findings in the United States of America and the United Kingdom on HE leadership development suggest that leaders do not necessarily need to have a clear sense of direction and what needs to be achieved. However, these leaders are obliged to engage all stakeholders in the HE vision (Hempsall, 2014, p. 391).

\subsubsection{Leadership development interventions}

Importantly, the aspect of leadership capabilities and leadership development interventions need to begin far earlier in the academic profession to ensure that success is built from below rather than from above (Spendlove, 2007, p. 414). MacGregor (2015, p. 30) asserts that the University of Free State (UFS) has allocated many resources into the succeeding generation of leaders. Moreover, Martin (2007) claims that in the future, essential skills for effective leadership fall in the category of relationships and teamwork. To build leadership capacity, HEIs must ensure that managers possess moral management, technical skills, astute social and emotional skills (Ngcamu \& Teferra, 2015a, p. 209). Hence, Lewis, Thomas, and Bradley (2012, p. 82) acknowledged that two components of leadership capabilities are learning from personal errors or faults and being aware of personal strengths and weaknesses. Furthermore, Ngcamu and Teferra (2015a, p. 210) asserted that a leader must first need to understand themselves and be skilled to transform organizations to become more effective.

Interestingly, Ngcamu and Teferra (2015a, p. 210) point out that it is important to listen to resistors as these people will help address and detect the impediments on the path and may offer positive viewpoints. As a leader develops a combination 
of personal behaviors, skills, and character, the leaders will flourish into more successful (Denton \& Vloeberghs, 2003, p. 93). Additionally, Cheng, Chang, Kuo, and Cheung (2014, p. 827) suggest that organizations should design and provide training courses to cultivate ethical leadership behavior.

\subsubsection{Ethics training and development}

Fast-changing technologies require heavy investment in staff development if employees are to improve skills and harness these technologies to the objectives of the university (African Minds, 2016 p. 67). However, the development of organizational ethics will not be valuable, devoid of the implementation of ethics training (Lloyd \& Mey, 2010, p. 3). Dorasamy (2012, p. 512) suggests that management should embark on organizational ethics programs that reflect clear support for whistleblowing and high ethical standards. Lloyd and Mey (2010, p. 14) pointed out that organizations attempting to execute ethics must take into consideration ethical learning and training. Lloyd and Mey (2010, p. 3) posit that persistent ethics education and training programs must be provided for all employees in the organization.

An ethical survey, as Lloyd and Mey (2010, p. 3), Nicolaides (2009, p. 490) asserted, claims that the ethics training that organizations offered was too short-term and excluded new employees and managers. Hence, to respond to the needs of the university, leadership development programs (junior, middle, and senior management levels) should be established to enhance leaders' capabilities (Ngcamu \& Teferra, 2015a, p. 214). Leadership development programs (LDPs) can reward HEIs and public as well as individual academics professionally and personally (Zuber-Skerritt \& Louw, 2014). Besides, Lloyd and Mey (2010, p. 3) suggest that ethics training should be launched with formal new employees' orientation programs and should be reinforced with continuous training interventions.

\section{AIM}

This paper aims primarily to examine whether ethical leadership training and development is needed at a South African higher education institution (SAHEI) in KwaZulu-Natal.

\section{METHODS}

The paper drew data from a mixed methodology approach using probability sampling and non-probability sampling techniques. The quantitative probability method used simple random sampling, and the non-probability qualitative method was based on purposive sampling. Simple random sampling for the quantitative component constituted a theoretical/target population of 1,874 , with a sampling population of 420 academic and administrative staff members at the institution. Structured questionnaires were randomly administered to the sample of 420 and 312 respondents; thus, a response rate of $74 \%$ was obtained. The purposeful sampling for the qualitative component was a planned sample of 6 executive management leadership (EML) and 12 line management leadership (LML) participants. However, the realized sample was three EML and nine LML for the interview response rate, which constituted 12 out of 18 interviews in total, indicating a total response rate of 67\%. Semi-structured interviews and open-ended interviews were used for the qualitative component of the study as data collection tools. All ethical considerations and protocols were observed in relation to obtaining ethical clearance, gatekeeper's letter, informed consent, and upholding anonymity and confidentiality.

\section{RESULTS}

This section outlines the quantitative findings pertaining primarily to training and development and its influence on ethical leadership. Table 1 was used to assist with understanding the strength of frequency distribution and mean score values.

The Executive Management Leadership (EML) was descriptively analyzed in conjunction with evidence of ethical leadership style. The study explored employee's stance on whether executive management leadership exhibits an ethical leadership style. The Table 1 depicted EML with respect to ethical leadership style. Table 1 utilized 5-point Likert rating scale statements from strongly disagree to strongly agree in descending order.

There were high levels of disagreements when it came to EML style: 
Table 1. EML items

\begin{tabular}{|c|c|c|c|c|c|c|c|c|}
\hline \multicolumn{5}{|l|}{ Likert scale } & \multirow[b]{2}{*}{ A } & \multirow[b]{2}{*}{ SA } & \multirow[b]{2}{*}{ Mean } & \multirow[b]{2}{*}{ Std. dev } \\
\hline \multicolumn{2}{|l|}{ Executive management leadership items } & SD & D & $\mathbf{N}$ & & & & \\
\hline \multirow{2}{*}{ Is my role model/mentor? } & Count & 76 & 81 & 89 & 46 & 20 & \multirow{2}{*}{2.53} & \multirow{2}{*}{1.192} \\
\hline & $\%$ & 24.4 & 26.0 & 28.5 & 14.7 & 6.4 & & \\
\hline \multirow{2}{*}{$\begin{array}{l}\text { Suggests different ways of resolving problems within the } \\
\text { faculty }\end{array}$} & Count & 56 & 66 & 97 & 69 & 24 & \multirow{2}{*}{2.80} & \multirow{2}{*}{1.194} \\
\hline & $\%$ & 17.9 & 21.2 & 31.1 & 22.1 & 7.7 & & \\
\hline \multirow{2}{*}{ Treats staff with respect and fairness } & Count & 53 & 65 & 94 & 70 & 30 & \multirow{2}{*}{2.87} & \multirow{2}{*}{1.218} \\
\hline & $\%$ & 17.0 & 20.8 & 30.1 & 22.4 & 9.6 & & \\
\hline \multirow{2}{*}{$\begin{array}{l}\text { Goes the extra mile to resolve staff issues in } \\
\text { departments }\end{array}$} & Count & 63 & 83 & 92 & 54 & 20 & \multirow{2}{*}{2.63} & \multirow{2}{*}{1.171} \\
\hline & $\%$ & 20.2 & 26.6 & 29.5 & 17.3 & 6.4 & & \\
\hline \multirow{2}{*}{ Able to resolve department problems promptly } & Count & 69 & 75 & 100 & 51 & 17 & \multirow{2}{*}{2.59} & \multirow{2}{*}{1.159} \\
\hline & $\%$ & 22.1 & 24.0 & 32.1 & 16.3 & 5.4 & & \\
\hline \multirow{2}{*}{ Is transparent and his/her conduct is positive } & Count & 66 & 60 & 100 & 62 & 24 & \multirow{2}{*}{2.74} & \multirow{2}{*}{1.217} \\
\hline & $\%$ & 21.2 & 19.2 & 32.1 & 19.9 & 7.7 & & \\
\hline Average mean & & & & & & & 2.74 & 0.033 \\
\hline
\end{tabular}

1) treats staff with respect and fairness was the highest mean value $(\mathrm{M}=2.87, \mathrm{SD}=1.218)$, with most of the respondents disagreeing (17\% strongly disagree and $20.8 \%$ disagree), suggests different ways of resolving problems within the faculty was the second highest mean value $(\mathrm{M}=2.80, \mathrm{SD}=1.194)$, with the majority of respondents disagreeing (17.9\% strongly disagree and $21.2 \%$ disagree), is transparent and his/her behavior is positive was the third highest mean value $(\mathrm{M}=2.74$, $\mathrm{SD}=1.217)$ with most respondent disagreeing (21.2\% strongly disagree and 19.2\% disagree);

2) goes the extra mile to resolve staff issues in departments being the fourth mean value
$(\mathrm{M}=2.63, \mathrm{SD}=1.171)$, with the majority of respondents disagreeing $(20.2 \%$ strongly disagree and $26.6 \%$ disagree), able to resolve department problems promptly being the fifth mean value $(M=2.59, \mathrm{SD}=1.159)$, with most respondents disagreeing (22.1\% strongly disagree and $24.0 \%$ agree), as my role model/ mentor being the sixth mean value and standard deviation $(\mathrm{M}=2.53, \mathrm{SD}=1.192)$, and the lowest, with most respondents disagreeing (24.4\% strongly disagree and $26.0 \%$ disagree).

\subsection{Leadership components}

The analysis shows one-sample statistics and one sample test for leadership components. Table 2 is

Table 2. One-sample test and one-sample statistics for three statements

\begin{tabular}{|c|c|c|c|c|}
\hline \multicolumn{5}{|c|}{ One-sample statistics } \\
\hline Leadership components & $\mathbf{N}$ & Mean & Std. deviation & Std. error mean \\
\hline $\begin{array}{l}\text { Leaders to attend ongoing leadership development } \\
\text { training courses during their term in office }\end{array}$ & 312 & $4.20^{*}$ & .904 & .051 \\
\hline $\begin{array}{l}\text { Ethical leadership style can have a positive impact on } \\
\text { employees }\end{array}$ & 312 & $4.43^{*}$ & .740 & .042 \\
\hline Leadership style has an impact on staff well-being & 312 & $4.24^{*}$ & .939 & .053 \\
\hline
\end{tabular}

\section{One-sample test}

\begin{tabular}{|c|c|c|c|c|c|c|}
\hline \multirow{3}{*}{ Leadership components } & \multicolumn{6}{|c|}{ Test value $=\mathbf{3}$} \\
\hline & \multirow[t]{2}{*}{$\mathbf{t}$} & \multirow[t]{2}{*}{ df } & \multirow{2}{*}{$\frac{\text { Sig. }}{(2-\text { tailed })}$} & \multirow{2}{*}{$\begin{array}{c}\text { Mean } \\
\text { difference }\end{array}$} & \multicolumn{2}{|c|}{$\begin{array}{l}95 \% \text { confidence interval } \\
\text { of the difference }\end{array}$} \\
\hline & & & & & Lower & Upper \\
\hline $\begin{array}{l}\text { Leaders to attend ongoing leadership development } \\
\text { training courses during their term in office }\end{array}$ & 23.479 & 311 & .000 & 1.202 & 1.10 & 1.30 \\
\hline $\begin{array}{l}\text { Ethical leadership style can have a positive impact on } \\
\text { employees }\end{array}$ & 34.107 & 311 & .000 & 1.429 & 1.35 & 1.51 \\
\hline Leadership style has an impact on staff well-being & 23.263 & 311 & .000 & 1.237 & 1.13 & 1.34 \\
\hline
\end{tabular}

Note: $*$ if significance and mean $>3.00=$ significant agreement. 
the one-sample statistics and one-sample test that showed statistically significant differences (agreement or disagreement).

These random statements did not measure any single construct in the study. However, these results revealed a statistical significant agreement $(p<0.05)$, as specified below:

- leadership style affects staff well-being $(\mathrm{M}=4.24, \mathrm{SD}=0.939), t(311)=23.263, p=0.000$;

- leaders to attend ongoing leadership training courses during their term in office $(\mathrm{M}=4.20$, $\mathrm{SD}=0.904), t(311)=23.479, p=0.000$;

- ethical leadership style can positively affect the employees. $(\mathrm{M}=4.43, \mathrm{SD}=0.740), t(311)$ $=34.107, p=0.000$.

Table 2 revealed a $p$-value $(<0.05)$ for overall 5 -point Likert scale rating statements. These statements displayed a very low standard deviation value; thus, formed a cluster variance of data. Accordingly, the results exhibited high $t$-value dimensions suggesting statistically significant results in $p$-value.

\subsection{Qualitative analysis}

The sample size of the qualitative arm of the study was $n=12$ participants. Various analysis techniques were used, such as word cloud, tree map, cluster analysis, and hierarchy charting to assist in the formulation of respective themes. The qualitative data hence adopted a thematic approached validated by the researchers' interpretation. The biographical information was presented in relation to different cohorts of leadership at the insti- tution. As mentioned above, the sample size was a complement of 12 out of 18 participants.

Figure 1 illustrated the frequency distribution of the participants' age category. The majority of participants were between 40 and 49 years (50\%), followed by 60 years and over (25\%), and between 50 and 59 years (17\%). Thus, the participants were mature in age (greater than 40 years), which supports their years of experience in the institution. However, the lowest percentage was 30-39 years (8\%), showing a possible need to build leadership capacity from a younger age, which has been concurred by Spendlove $(2007$, p. 414$)$ that from the aspect of leadership capabilities, leadership development interventions need to begin far earlier in the academia profession to ensure that success is built from below rather than from above.

\subsection{Emphasis on leadership development and training}

\subsubsection{Executive management leadership}

Some participants felt that there was a need for executive management to attend training and development programs. These programs could assist in promoting ethical behavior at the executive level.

As per participant 12, "Executive managers need to attend leadership training and development programs in order to practice ethical behavior in their ambit". It could reinforce executive managerial skills and be a nice refresher for those that may have forgotten such skills. The programs could help executive management become more sensitive to the employee. As per participant 6, "Some leaders need to have training in practicing compassion towards the employee. Employees with chronic illnesses are be-

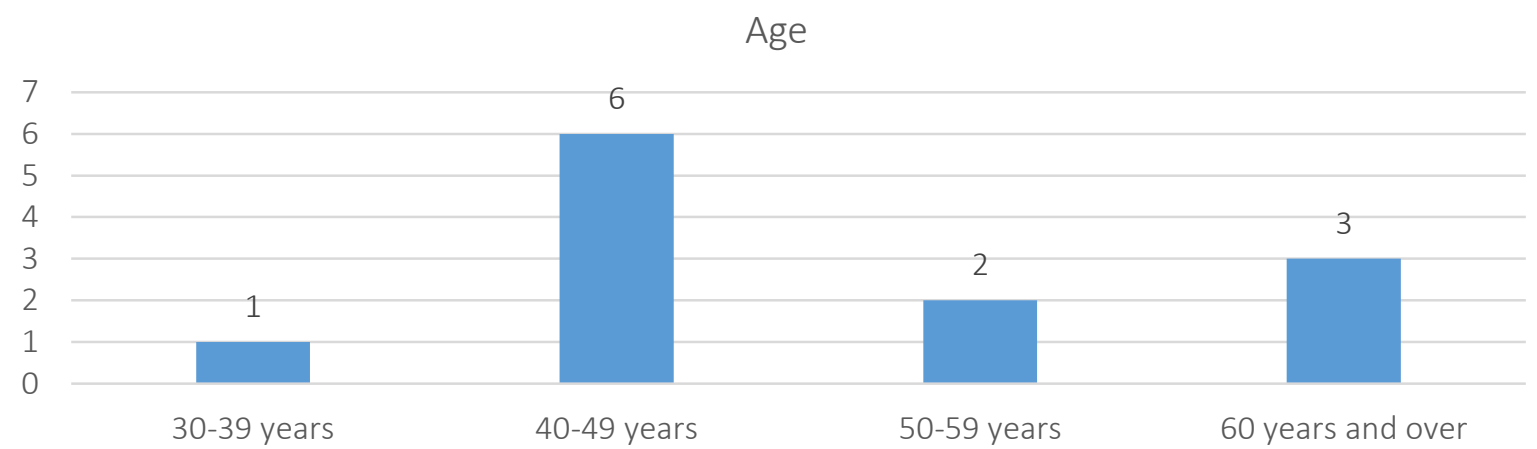

Figure 1. Age category of leadership 
ing treated badly". Conversely, some participants felt that there was no need for executive leadership to attend training, since they should already have these skills being executive managers. As per participant 9, "Executive managers do not need to attend leadership training and development programs. At their level of seniority, they should be able to demonstrate their leadership".

\subsubsection{Line management leadership}

When it came to line management leadership training and development, only $50 \%$ of the participants felt it was appropriate for the following reasons:

- was helpful to new line management leadership that were just starting in their roles. Besides, these programs are providing good managerial skills and are taught how to manage processes and people differently, and it builds leadership capacity. As per participant 8, "These university leadership and development programs are appropriate";

- surprisingly, there were 6 out of 12 participants $(50 \%)$ that agreed they did not attend ethical leadership programs, and 3 out of the 6 participants felt they were a waste of time; they were inappropriate and unhelpful to them. Some felt that these programs were just for the sake of ticking boxes;

- $\quad$ as per participant 5, "University leadership and development programs are inappropriate and a waste of time". Another participant did not know of such program, which is consistent with participant 1 "There are no university ethical leadership training and development programs";

- interestingly, 4 out of 12 participants (33\%) asserted that there are sufficient ethical leadership training and development workshops that they have attended. As per participant 9, "I have attended ethical leadership training and development workshops";

- additionally, the lack of HR performance management systems made these programs ineffective. As per participant 7, "Yes, generally these programs are helpful; however, human resource processes and performance management systems are not in place rendering these programs ineffective". There should be more training and development workshops to assist line management in dealing with challenges that can/may affect them. Currently, there are a limited number of such workshops, as participant 9 asserted, "There are other issues that hinder my leadership abilities, I think more of these workshops can be arranged for line management". Moreover, while the workshops are seen as good, it differs from the real-life working environment. The real-life working environment has real people, real processes, and real issues.

The results from EML style (Table 1) reflect the average mean values $(\mathrm{M}=2.74, \mathrm{SD}=0.033)$, which revealed that the strength of the mean value scores is weak across all statements. Hence, a weak mean score value for executive management leadership. Results imply that employees were currently not happy with current EML style in relation to treating staff with respect and fairness, suggesting different ways of resolving problems, transparency, and behavior, resolving staff and departmental issues, and being a role model/mentor. Besides, Table 2 shown a significant agreement for leadership dimension at the institution when it comes to leaders attending ongoing leadership training courses during their term in office and ethical leadership style having a positive impact on employees. Furthermore, qualitative analysis shows a need for EML to attend training and development programs to reinforce their managerial skills and become more sensitive, compassionate, and ethical leaders. From an LML perspective, only 50\% of the participants felt that training and development was appropriate primarily for promoting good leadership skills towards staff. The other $50 \%$ felt that such programs would be a waste of time and did not attend. Further, the results showed a need for performance management systems to facilitate training and development programs.

\section{DISCUSSION}

From a quantitative perspective, the results emphasize that leaders must attend ongoing leadership training courses during their term in office. The findings showed a need for all level managers 
to attend leadership and development training programs. These results imply that employees believe managers lack the leadership skills to manage departments effectively. Importantly, managers need to attend appropriate leadership programs, which are designed specifically for the university environment. Besides, respondents have significantly agreed (Table 2) that leaders need to attend ongoing leadership courses during their term in office. Lloyd and Mey (2010, p. 3) posit that persistent ethics education and training programs must be provided for all employees in the organization.

The qualitative aspect revealed the lowest percentage for the biographical information of the age category of leadership was between 30 and 39 years (8\%). This showed a possible need to build leadership capacity from a younger age. This concurs with Spendlove (2007, p. 414) that from the aspect of leadership capabilities, leadership development interventions need to begin far earlier in the academic profession to ensure that success is built from below rather than from above. The findings showed a need for all level managers to attend leadership and development training programs. These results imply that employees believe managers lack the leadership skills to manage departments effectively. This is homogenous with Ngcamu and Teferra (2015a, p. 208) assertion that most of the HEIs have given little attention to leadership development that caused ineffectiveness and lack of leadership capabilities. Importantly, managers need to attend appropriate leadership programs, which are designed specifically for the university environment. Moreover, when introducing ethical training and ethical leadership into the program, as Lloyd and Mey (2010, pp. 14) asserted, the organizations attempting to execute ethics must take into consideration ethical learning and training programs.

Importantly, more than $50 \%$ (6 out of 12) of the participants revealed no appropriate university leadership programs or ethical leadership programs. Interestingly, only a few participants believed that executive management leadership should attend leadership programs. However, this is opposite to Durban University of Technology (2016, pp. 61-62) that the institutions' council governance workshop or forum ensures close engagement and guidance for executive and senior management level. These findings have highlighted the need for executive management to attend appropriate ethical leadership programs that will facilitate and strengthen leadership.

Overall, the results imply that the different levels of leadership (EML and LML) currently lack training and development when it comes to ethical leadership. Employees feel that EML style is currently not up to ethical standards based on the disagreement levels on the factors listed in Table 1. The EML needs to become constituent to mandatory leadership training and development programs that staff will appreciate when it comes to ethics and transparency. Besides, LML also needs equal efforts as a considerable percentage did not even attend training programs, while some were not aware of such programs, and some felt it was a waste of time. In summary, these results paint a bleak current picture of training and development for ethical leadership at the institution. However, in relation to the aim of the study, the results imply that training and development can promote ethical leadership at the institution.

\section{CONCLUSION}

The study concludes that there currently exists a need for training and development to foster ethical leadership style at the institution. The study showed evidence of poor ethical leadership qualities by executive management leadership in relation to respect and fairness, transparency, among others, and this can negatively affect the employees. Compounding this is the lack of training and development when it comes to supporting and promoting ethical leadership at the institution. This can imply that the lack of leadership training and development programs contributes to poor executive management leadership style at the institution. In light of this, the results showed a clear need for leadership to attend ongoing training and development courses that will support higher education leadership at all levels. This can improve an effective leadership style with the potential of having a positive impact on the employees. 
Therefore, there was an emphasis on the need for leadership staff to attend ethical leadership training and development programs and develop themselves accordingly, which was evidently supported by respondents. Recommendations can include the development of specific or custom ethical training programs made compulsory for all leadership levels. This can also be included in the institutions' strategic plan and wide training and development framework or model geared specifically towards ethical leadership.

\section{REFERENCES}

1. African Minds (2016). Reflections of South African university leaders: 1981 to 2014 (200 p.). Retrieved from http://www.africanminds. co.za/reflections-of-south-africanuniversity-leaders-1981-to-2014

2. Awung, M. (2015). Factors influencing the career progression of women in higher education: the case of the Durban University of Technology (157 p.). South Africa: Durban University of Technology. Retrieved from https://pdfs. semanticscholar.org/a6b2/4ac28 5f61975b5257f0f3ea0028e17ea0 0d4.pdf

3. Bush, T. (2007). Educational leadership and management: theory, policy and practice. South African Journal of Education, 27(3), 391-406. Retrieved from https:// www.ajol.info/index.php/saje/article/view/25107

4. Cheng, J., Chang, S., Kuo, J., \& Cheung, Y. (2014). Ethical leadership, work engagement, and voice behavior. Industrial Management \& Data Systems, 114(5), 817-831. https://doi. org/10.1108/IMDS-10-2013-0429

5. de la Rey, C. (2015). Governance and Management in Higher Education (briefing paper prepared for the second national Higher Education Transformation Summit). Retrieved from https:// www.justice.gov.za/commissions/ feeshet/docs/2015-HESummitAnnexure15.pdf

6. Denton, M., \& Vloeberghs, D. (2003). Leadership challenges for organisations in the new South Africa. Leadership \& Organization Development Journal, 24(2), 84-95. https://doi. org/10.1108/01437730310463279

7. Dorasamy, N. (2012). Institutionalising a whistle blowing culture within higher education institutions: policy and procedure underpinning good governance at the Durban University of Technology. Journal of Economics and Behavioral Studies, 4(9), 505-514. Retrieved from http://hdl.handle. net/10321/1148

8. Durban University of Technology (2016). Annual Report 2016. Retrieved from https://www. dut.ac.za/wp-content/uploads/2012/06/DUT_AR2016_ web.pdf

9. Greasley, K., Bryman, A., Dainty, A., Price, A., \& Naismith, N. (2008). Understanding empowerment from an employee perspective: What does it mean and do they want it? Team Performance Management, 14(1/2), 39-55. https://doi. org/10.1108/13527590810860195

10. Gumede, W. (2015). Fostering a common SADC regional identity through higher education institutions. African Journal of Public Affairs, 7(4), 156-176. Retrieved from https://www. semanticscholar.org/paper/Fostering-a-common-SADC-regionalidentity-through-Gumede/9a77f 8b9a6b79fd6cee3b88cd8a692f51 aa $3 \mathrm{cfc} 5$

11. Hanson, K., \& Léautier, F. (2011). Enhancing institutional leadership in African universities: lessons from ACBS's interventions. World Journal of Entrepreneurship, Management and Sustainable Development, 7(2/3/4), 385-417. https://doi. org/10.1108/20425961201000040

12. Hempsall, K. (2014). Developing leadership in higher education: perspectives from the USA, the UK and Australia. Journal of Higher Education Policy and
Management, 36(4), 383-394. https://doi.org/10.1080/136008 0X.2014.916468

13. Herbst, T., \& Conradie, P. (2011). Leadership effectiveness in Higher Education: Managerial selfperceptions versus perceptions of others. SA Journal of Industrial Psychology, 37(1), 1-14. http:// dx.doi.org/10.4102/sajip.v37i1.867

14. Hudea, O. (2014). Leadership development. Manager, 20(1), 110-114. Retrieved from https:// econpapers.repec.org/RePEc:but: manage:v:20:y:2014:i:1:p:110-114

15. Kivipõld, K., \& Vadi, M. (2008). A tool for measuring institutional leadership and its implementation for the evaluation of organizational leadership capability (Working Paper) (17 p.). Retrieved from https://econpapers.repec.org/ paper/ttuwpaper/172.htm

16. Kouzes, J., \& Posner, B. (2003a). The leadership practices inventory (LPI) (participant's workbook) (3rd ed.) (48 p.). San Francisco: John Wiley \& Sons. Retrieved from https://www.amazon.com/ Leadership-Practices-InventoryLPI-Participants/dp/0787967262

17. Leibowitz, B., Bozalek, V., van Schalkwyk, S., \& Winberg, C. (2015). Institutional context matters: The professional development of academics as teachers in South African higher education. Higher Education, 69(2), 315-330. https://doi. org/10.1007/s10734-014-9777-2

18. Lewis, A., Thomas, B., \& Bradley, O. (2012). Employee socialisation: a platform for employee engagement? International Journal of Employment Studies, 20(1), 25. Retrieved from https:// www.questia.com/library/ journal/1G1-308883457/employ- 
ee-socialisation-a-platform-foremployee-engagement

19. Lloyd, H., \& Mey, M. (2010). An ethics model to develop an ethical organisation. SA Journal of Human Resource Management, 8(1), 1-12. https://doi.org/10.4102/ sajhrm.v8i1.218

20. Mabelebele, J. (2013). Why Governance, Leadership and Management in Higher Education matter? Retrieved from http:// www.usaf.ac.za/wp-content/uploads/2017/02/Address-at-HELMLead-workshop-15-Oct13.pdf

21. MacGregor, K. (2015). Thoughts and Experiences of African University Leaders. Retrieved from https://www.universityworldnews.com/post. php?story $=20150306095945342$

22. Martin, A. (2007). The changing nature of leadership. Center for Creative Leadership.

23. Naidu-Hoffmeester, R. (2014). Convocation discusses South Africa's leadership challenges. SA leadership challenges. Johannesburg: Wits University. Retrieved from www.wits.ac.za

24. Naino, A. (2016). Ethics - the tiny voice that is frequently ignored. South African Institute of Professional Accountant, 27, 17. Retrieved from https://journals. co.za/content/account/2016/27/ EJC188564

25. Ngcamu, B. S., \& Teferra, D. (2015a). Leadership and transformation in a South African university. Problems and Perspectives in Management, 13(1), 208-216. Retrieved from https:// businessperspectives.org/journals/ problems-and-perspectives-inmanagement/issue-1-cont-4/ leadership-and-transformationin-a-south-african-university

26. Ngcamu, B., \& Teferra, D. (2015b). The effect of skills development programmes and leadership opportunities brought by transformation: a case of the Durban University of Technology. Journal of Social Sciences, 45(2), 130-139. https://doi.org/10.1080/0 9718923.2015.11893494

27. Sankar, Y. (2003). Character not charisma is the critical measure of leadership excellence. Journal of Leadership \& Organizational Studies, 9(4), 45-55. https://doi.org /10.1177\%2F107179190300900404

28. Spendlove, M. (2007). Competencies for effective leadership in higher education. International Journal of Educational Management, 21(5), 407-417. https://doi. org/10.1108/09513540710760183
29. Taylor, J., \& Machado, M. (2006). Higher education leadership and management: From conflict to interdependence through strategic planning. Tertiary Education and Management, 12(2), 137-160. https://doi.org/10.1007/s11233006-0003-3

30. van Niekerk, M. (2005). Transformational leadership at a higher education institution (Ph.D. thesis). South Africa: University of South Africa. Retrieved from http://hdl.handle.net/10500/1601

31. van Schalkwyk, F., Willmers, M., \& Czerniewicz, L. (2014). Open data in the governance of South African higher education (research report) (55 p.). https://doi.org/10.6084/ M9.FIGSHARE. 1128608

32. Zuber-Skerritt, O. (2007). Leadership development in South African higher education: The heart of the matter. South African Journal of Higher Education, 21(7), 984-1005. https://doi.org/10.4314/ sajhe.v21i7.25756

33. Zuber-Skerritt, O., \& Louw, I. (2014). Academic leadership development programs: A model for sustained institutional change. Journal of Organizational Change Management, 27(6), 1008-1024. https://doi.org/10.1108/JOCM-112013-0224 